\title{
Simultaneous synthesis of molybdenum carbides and titanium carbides by sol-gel method
}

\author{
A. Biedunkiewicz $\cdot$ P. Figiel $\cdot$ M. Krawczyk $\cdot$ \\ U. Gabriel-Polrolniczak
}

Received: 15 October 2012/Accepted: 3 April 2013/Published online: 30 April 2013

(C) The Author(s) 2013. This article is published with open access at Springerlink.com

\begin{abstract}
The research on simultaneous synthesis of molybdenum carbides and of titanium carbides by sol-gel method was conducted. $\left(\mathrm{NH}_{4}\right)_{6} \mathrm{Mo}_{7} \mathrm{O}_{24} \cdot 4 \mathrm{H}_{2} \mathrm{O}$ and $\mathrm{Ti}\left[\mathrm{O}\left(\mathrm{CH}_{2}\right)_{2} \mathrm{CH}_{3}\right]_{4}$ were applied as precursors. The gaseous products were determined using mass spectrometry method. The phase composition of samples was identified by XRD method, and their morphology was examined by SEM method. After the hydrolysis of $\operatorname{Ti}\left[\mathrm{O}\left(\mathrm{CH}_{2}\right)_{2} \mathrm{CH}_{3}\right]_{4}$ nanometric $\mathrm{TiO}_{2}$ was received. Before the synthesis $\left(\mathrm{NH}_{4}\right)_{6} \mathrm{Mo}_{7} \mathrm{O}_{24} \cdot 4 \mathrm{H}_{2} \mathrm{O}$ decomposed into $\mathrm{MoO}_{3}(t \leq 673 \mathrm{~K})$. At the temperature of $689-943 \mathrm{~K} \mathrm{MoO}_{3}$ was reduced into $\mathrm{MoO}_{2}$ (or also into Mo). The synthesis of $\mathrm{Mo}_{2} \mathrm{C}$ proceeded at the temperature of $973-1,189 \mathrm{~K}$. In this temperature range also reduction of $\mathrm{TiO}_{2}$ into $\mathrm{Ti}_{\mathrm{x}} \mathrm{O}_{\mathrm{y}}$ took place. The synthesis of titanium carbides proceeded at the temperature $t \geq 1,285 \mathrm{~K}$.
\end{abstract}

Keywords Synthesis of carbides · Sol-gel method . Mo-Ti-active carbon system

\section{Introduction}

In the Mo-Ti-C system, it is possible to obtain a number of phases, such as $\mathrm{TiC}$ and $\mathrm{Mo}_{2} \mathrm{C}$. TiC is characterised by high hardness, strength, high Young modulus and high

\footnotetext{
A. Biedunkiewicz · P. Figiel · M. Krawczyk $(\bowtie)$

Institute of Materials Science and Engineering, West

Pomeranian University of Technology, Szczecin, Piastow Av.

19, Szczecin, West Pomeranian, Poland

e-mail: mkrawczyk@zut.edu.pl

U. Gabriel-Polrolniczak

Department of Physics and Chemistry, Maritime University of

Szczecin, Waly Chrobrego 1-2, Szczecin, Poland
}

wear resistance at relatively low density. $\mathrm{Mo}_{2} \mathrm{C}$ is characterized by high hardness and wear resistance, it is fireresistant and catalytically active.

The addition of $\mathrm{Mo}_{2} \mathrm{C}$ and $\mathrm{TiC}$ to the cermets has remarkably improved their mechanical properties and microstructure [1].

Analysis of the course of the process of simultaneous synthesis of molybdenum carbides and titanium carbides was the aim of this study. Composites of transition metals carbides often demonstrate better properties than the individual components. In a standard way such composites are obtained by mixing the prepared carbides. The components are present in such mixture as separate phases. It was assumed, that by carrying out the simultaneous synthesis of the components a better homogenization will be obtained. In general, the studies concerned the synthesis of transition metal carbides in multistage processes, involving nanometric reagents [2-6].

$\left(\mathrm{NH}_{4}\right)_{6} \mathrm{Mo}_{7} \mathrm{O}_{24} \cdot 4 \mathrm{H}_{2} \mathrm{O}$ and $\mathrm{Ti}\left[\mathrm{O}\left(\mathrm{CH}_{2}\right)_{2} \mathrm{CH}_{3}\right]_{4}$ were used as precursors. The initial composition of the samples was specified by giving, expressed in atomic units, the Mo/Ti proportion and the carbon content expressed according to $\mathrm{C} /\left(\mathrm{MoO}_{3}+\mathrm{TiO}_{2}\right)$ mole mole ${ }^{-1}$. This way was chosen because during the hydrolysis of $\operatorname{Ti}\left[\mathrm{O}\left(\mathrm{CH}_{2}\right)_{2} \mathrm{CH}_{3}\right]_{4}$ at low temperature the nanometric $\mathrm{TiO}_{2}$ is received, and $\left(\mathrm{NH}_{4}\right)_{6} \mathrm{Mo}_{7} \mathrm{O}_{24} \cdot 4 \mathrm{H}_{2} \mathrm{O}$, before the synthesis of carbides $(t \leq 670 \mathrm{~K})$, decomposes into $\mathrm{MoO}_{3}$ [7]. Thus, the synthesis of carbides proceeded in the system $\mathrm{MoO}_{3}-\mathrm{TiO}_{2}-$ active carbon. In the study [8], the results of research on the synthesis of mixed carbides ( $\mathrm{Ti}, \mathrm{Mo}) \mathrm{C}$ were described. It was reported that they are characterized by good properties as ceramic materials. It should be noted that in case of carbides syntheses in multicomponent systems phase diagrams have important meaning. Phase diagram of the Mo$\mathrm{Ti}-\mathrm{C}$ system has been given in work [9]. 


\section{Experimental}

$\left(\mathrm{NH}_{4}\right)_{6} \mathrm{Mo}_{7} \mathrm{O}_{24} \cdot 4 \mathrm{H}_{2} \mathrm{O} \quad$ (Chempur), $\quad \operatorname{Ti}\left[\mathrm{O}\left(\mathrm{CH}_{2}\right)_{2} \mathrm{CH}_{3}\right]_{4}$ (Aldrich), active carbon (Carbo Aktiv from Alforam Fabryka Lekow Sp. z.o.o.), ethyl alcohol (Chempur), concentrated solution of $\mathrm{NH}_{4} \mathrm{OH}$ (Sigma Aldrich) and argon 6.0 (Messer) were used.

Thermogravimetric measurements were carried out on SDT Q 600 apparatus (TA Instruments). Volatile products of proceeding transitions were identified by mass spectrometry method. Pfeiffer Vacuum ThermoStar GDS 301 apparatus was used. While investigating the influence of parameters on the phase structure, the samples, placed in quartz tube under an argon flow, were heated in the furnace with programed temperature. The phase structure of solid products was identified by XRD method. X'Pert apparatus from PANalytical with a copper X-ray tube with current voltage of $35 \mathrm{kV}$ and intensity of $30 \mathrm{~mA}$ was used. Processing and analysis of XRD spectra was performed using X'Pert HighScore 2.2 software with incorporated ICDD spectra library. Morphology of the samples was studied by SEM method. HITACHI SU apparatus with THERMO FISHER NORAN 7 microanalysis adapter was used.

Thermal decomposition of $\left(\mathrm{NH}_{4}\right)_{6} \mathrm{Mo}_{7} \mathrm{O}_{24} \cdot 4 \mathrm{H}_{2} \mathrm{O}$ in argon, $\mathrm{Mo}_{2} \mathrm{C}$ synthesis in $\left(\mathrm{NH}_{4}\right)_{6} \mathrm{Mo}_{7} \mathrm{O}_{24} \cdot 4 \mathrm{H}_{2} \mathrm{O}$-active carbon system and synthesis of carbides in $\left(\mathrm{NH}_{4}\right)_{6} \mathrm{Mo}_{7} \mathrm{O}_{24} \cdot 4 \mathrm{H}_{2} \mathrm{O}$ $\mathrm{Ti}\left[\mathrm{O}\left(\mathrm{CH}_{2}\right)_{2} \mathrm{CH}_{3}\right]_{4}$-active carbon system were investigated. In the first case the purchased $\left(\mathrm{NH}_{4}\right)_{6} \mathrm{Mo}_{7} \mathrm{O}_{24} \cdot 4 \mathrm{H}_{2} \mathrm{O}$ was used directly. The samples for $\mathrm{Mo}_{2} \mathrm{C}$ synthesis in $\left(\mathrm{NH}_{4}\right)_{6} \mathrm{Mo}_{7} \mathrm{O}_{24}$. $4 \mathrm{H}_{2} \mathrm{O}$-active carbon system were obtained as follows: $5 \mathrm{~g}$ of $\left(\mathrm{NH}_{4}\right)_{6} \mathrm{Mo}_{7} \mathrm{O}_{24} \cdot 4 \mathrm{H}_{2} \mathrm{O}$ were mixed with $3.403 \mathrm{~g}$ of active carbon and ground in agate mortar. The sample of composition $\mathrm{C} / \mathrm{MoO}_{3}=10$ mole mole ${ }^{-1}$ was obtained. Then, $30 \mathrm{~cm}^{3}$ of ethyl alcohol was added. The sample was left at the room temperature for $24 \mathrm{~h}$. The volatile components were evaporated in an oil bath and the sample was dried at temperature of $383 \mathrm{~K}$. The excess of the carbon was applied to ensure a complete conversion of the molybdenum.

While carrying out the synthesis of carbides in $\left(\mathrm{NH}_{4}\right)_{6} \mathrm{Mo}_{7} \mathrm{O}_{24} \cdot 4 \mathrm{H}_{2} \mathrm{O}-\mathrm{Ti}\left[\mathrm{O}\left(\mathrm{CH}_{2}\right)_{2} \mathrm{CH}_{3}\right]_{4}$-active carbon system the samples of different reagents content were used. The ratios of molybdenum and titanium were changed in the range of $0.1 \leq \mathrm{Mo} / \mathrm{Ti} \leq 4.02$, and the carbon content in the range of $2.2 \leq \mathrm{C} /\left(\mathrm{MoO}_{3}+\mathrm{TiO}_{2}\right) \leq 18.17$ mole mole $^{-1}$.

The composition of the samples was determined basing on the phase equilibrium system Mo-Ti-C. As a catalyst of $\mathrm{Ti}\left[\mathrm{O}\left(\mathrm{CH}_{2}\right)_{2} \mathrm{CH}_{3}\right]_{4}$ hydrolysis $\mathrm{NH}_{4} \mathrm{OH}$ was used.

\section{Results}

The course of the process was considered on the basis of thermogravimetric studies. In turn the influence of parameters (initial composition of mixtures, temperature, time of samples heating) on the phase structure of received materials after the synthesis was determined on the basis of syntheses conducted under argon atmosphere in the furnace with programed temperature.

\section{Thermogravimetric studies}

The samples were heated in argon at the heating rate of 5 and $10 \mathrm{~K} \mathrm{~min}^{-1}$. The mass of the samples was in the order of $30 \mathrm{mg}$. The changes of sample temperature in time, TG, DTG and HF functions and mass spectra of volatile products were registered.

Figure 1 presents the comparison of trajectories of DTG curves registered during the thermal decomposition of the samples of compositions: (1) $\left(\mathrm{NH}_{4}\right)_{6} \mathrm{Mo}_{7} \mathrm{O}_{24} \cdot 4 \mathrm{H}_{2} \mathrm{O}$ (heating at $673 \mathrm{~K}$ for $1 \mathrm{~h})$; (2) $\left(\mathrm{NH}_{4}\right)_{6} \mathrm{Mo}_{7} \mathrm{O}_{24} \cdot 4 \mathrm{H}_{2} \mathrm{O}$-active carbon $\mathrm{C} / \mathrm{MoO}_{3}=10$ mole mole ${ }^{-1}$ (heating at $1,273 \mathrm{~K}$ for $1 \mathrm{~h}$ ); (3) $\left(\mathrm{NH}_{4}\right)_{6} \mathrm{Mo}_{7} \mathrm{O}_{24} \cdot 4 \mathrm{H}_{2} \mathrm{O}-\mathrm{TiO}_{2}$-active carbon $\mathrm{Mo} / \mathrm{Ti}=$ 1.6 mole mole ${ }^{-1} ; \quad \mathrm{C} /\left(\mathrm{MoO}_{3}+\mathrm{TiO}_{2}\right)=4$ mole mole ${ }^{-1}$ (heating at $1,473 \mathrm{~K}$ for $1 \mathrm{~h}$ ). The sample heating rate equalled $5 \mathrm{~K} \mathrm{~min}^{-1}$.

In all the cases there were distinguished: decomposition of $\left(\mathrm{NH}_{4}\right)_{6} \mathrm{Mo}_{7} \mathrm{O}_{24} \cdot 4 \mathrm{H}_{2} \mathrm{O}$ into $\mathrm{MoO}_{3}$, reduction of $\mathrm{MoO}_{3}$ into $\mathrm{MoO}_{2}$ (or also into Mo), and synthesis of $\mathrm{Mo}_{2} \mathrm{C}$. On the basis of the carried out measurements one can conclude, that as a result of $\mathrm{TiO}_{2}$ reduction the DTG peak, related to the synthesis of $\mathrm{Mo}_{2} \mathrm{C}$, is shifted into the range of higher temperature.

In Fig. 2 the plots of DTG and mass spectra of $\mathrm{H}_{2} \mathrm{O}$ $(m / e=18), \quad \mathrm{NH}_{3} \quad(m / e=17), \quad \mathrm{NO} \quad(m / e=30), \quad \mathrm{CO}$ $(m / e=28), \mathrm{CO}_{2}(m / e=44)$ and $\mathrm{C}(m / e=12)$ registered at heating rate of $5 \mathrm{~K} \mathrm{~min}^{-1}$ for the sample of composition

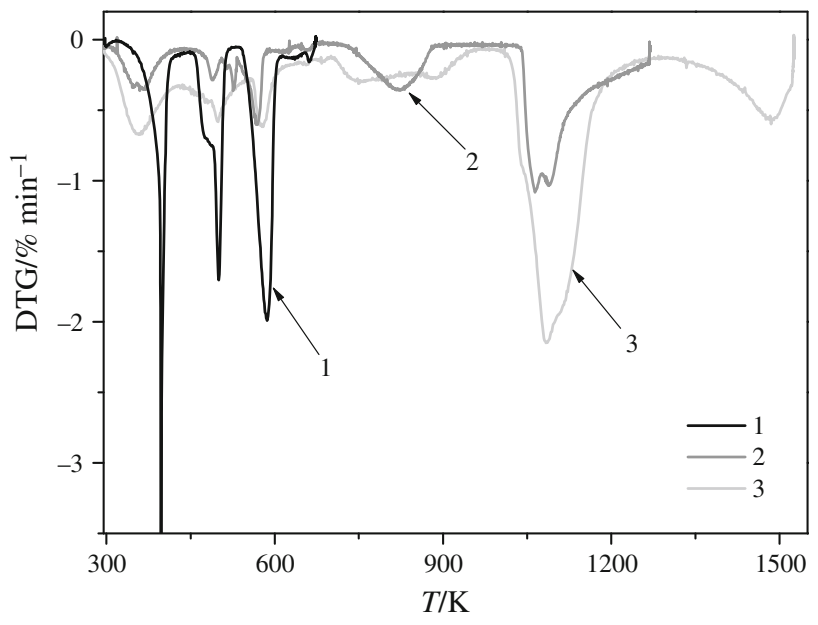

Fig. 1 Plots of DTG function in temperature. Heating of the samples of compositions: (1) $\left(\mathrm{NH}_{4}\right)_{6} \mathrm{Mo}_{7} \mathrm{O}_{24} \cdot 4 \mathrm{H}_{2} \mathrm{O}$; (2) $\left(\mathrm{NH}_{4}\right)_{6} \mathrm{Mo}_{7} \mathrm{O}_{24} \cdot 4 \mathrm{H}_{2} \mathrm{O}-$ active carbon (3) $\left(\mathrm{NH}_{4}\right)_{6} \mathrm{Mo}_{7} \mathrm{O}_{24} \cdot 4 \mathrm{H}_{2} \mathrm{O}-\mathrm{Ti}\left[\mathrm{O}\left(\mathrm{CH}_{2}\right)_{2} \mathrm{CH}_{3}\right]_{4}$-carbon under argon atmosphere. The sample heating rate $5 \mathrm{~K} \mathrm{~min}^{-1}$ 
$\mathrm{Mo} / \mathrm{Ti}=1.6$ mole mole ${ }^{-1} ; \quad \mathrm{C} /\left(\mathrm{MoO}_{3}+\mathrm{TiO}_{2}\right)=$ 4 mole mole ${ }^{-1}$ heated up to $1,523 \mathrm{~K}$ are presented as an example.

$\mathrm{H}_{2} \mathrm{O}, \mathrm{NH}_{3}$, NO were evolved during the decomposition of $\left(\mathrm{NH}_{4}\right)_{6} \mathrm{Mo}_{7} \mathrm{O}_{24} \cdot 4 \mathrm{H}_{2} \mathrm{O}$ in all the cases. It is noteworthy that $\mathrm{NO}$ was formed as a result of oxidation of produced $\mathrm{NH}_{3}$, by oxygen contained in argon at trace level. During the reduction of $\mathrm{MoO}_{3}$ into $\mathrm{MoO}_{2}$ (or also into $\mathrm{Mo}$ ) $\mathrm{CO}_{2}$ was mainly produced, and during the synthesis of $\mathrm{Mo}_{2} \mathrm{C}$ mainly $\mathrm{CO}$ was formed. In the last stage $\mathrm{CO}_{2}$ and $\mathrm{CO}$ were formed. In all the tests the stipulated stages of the process were distinguished.
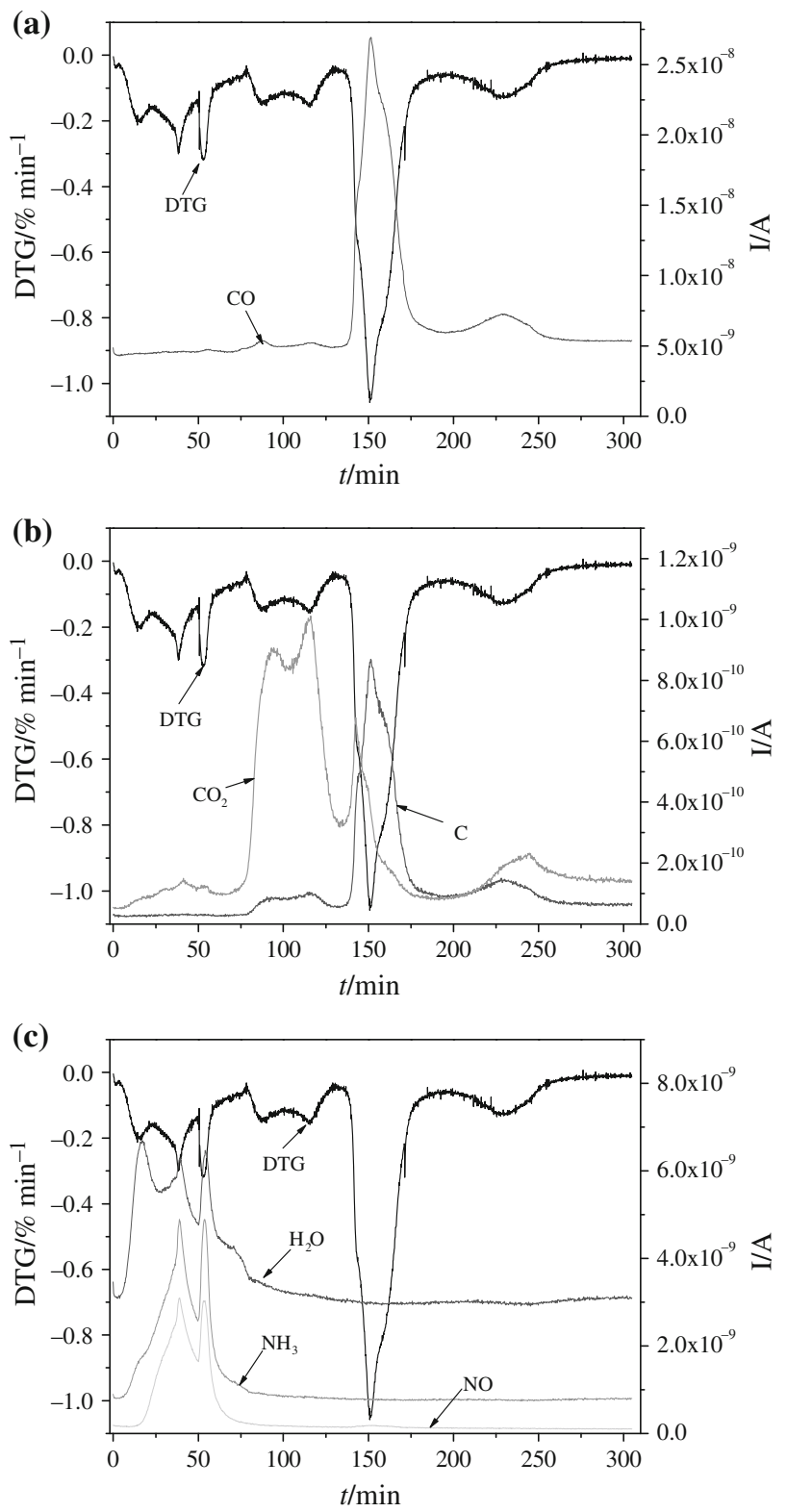

Fig. 2 Plots of DTG and mass spectra of $\mathrm{H}_{2} \mathrm{O}, \mathrm{NH}_{3}, \mathrm{NO}, \mathrm{C}$, $\mathrm{CO}, \mathrm{CO}_{2}$. Heating of the sample of composition $\mathrm{Mo} / \mathrm{Ti}=$ 1.6 mole mole ${ }^{-1} ; \quad \mathrm{C} /\left(\mathrm{MoO}_{3}+\mathrm{TiO}_{2}\right)=4$ mole mole ${ }^{-1}$ up to $1,523 \mathrm{~K}$ at heating rate of $5 \mathrm{~K} \mathrm{~min}^{-1}$ in $\operatorname{argon}$

\section{Influence of parameters on phase composition of samples after synthesis}

The measurements were carried out at temperature of $1,523 \mathrm{~K}$. At this temperature carbothermal reduction of nanometric $\mathrm{TiO}_{2}$ takes place [3]. Figure 3 shows, as an example, XRD diffractogram and scanning image of the sample of composition $\mathrm{Mo} / \mathrm{Ti}=1.6$ mole mole ${ }^{-1}$; $\mathrm{C} /\left(\mathrm{MoO}_{3}+\mathrm{TiO}_{2}\right)=3$ mole mole ${ }^{-1}$ after heating in argon at $1,523 \mathrm{~K}$ for $4 \mathrm{~h}$.

The analysis of phase composition of the sample realised by XRD method demonstrated, that the dominating phase was $\mathrm{Mo}_{2} \mathrm{C}$ (ICDD Card 00-035-0787) and the additional phase was TiC (ICDD Card 00-001-1222) and free Mo (ICDD Card 00-042-1120). The trace amounts of $\mathrm{TiO}_{2}$ (ICDD Card 01-087-0710) were also identified. The identification of molybdenum and titanium by EDS method suggests that the composite phases containing $\mathrm{Mo}_{2} \mathrm{C}$ and TiC occur in the powder particles. In the analyzed area with a diameter of $2 \mu \mathrm{m}$ homogeneous distribution of $\mathrm{Ti}$ and Mo was observed.

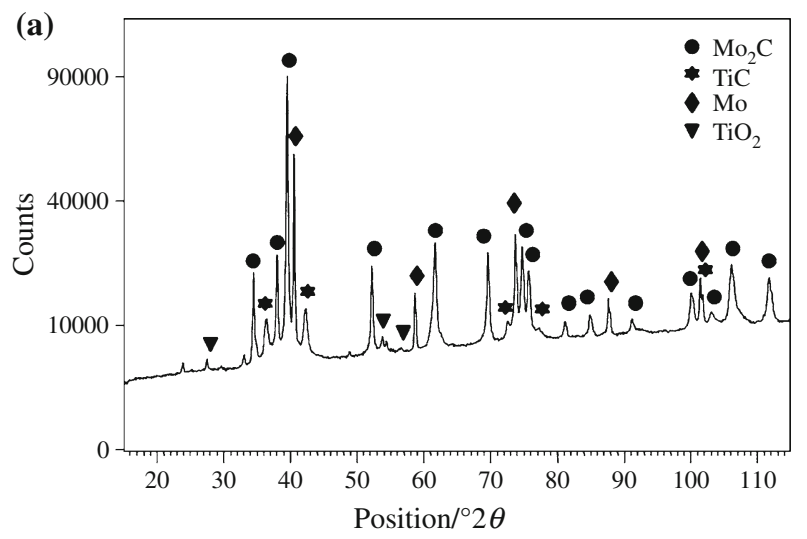

(b)

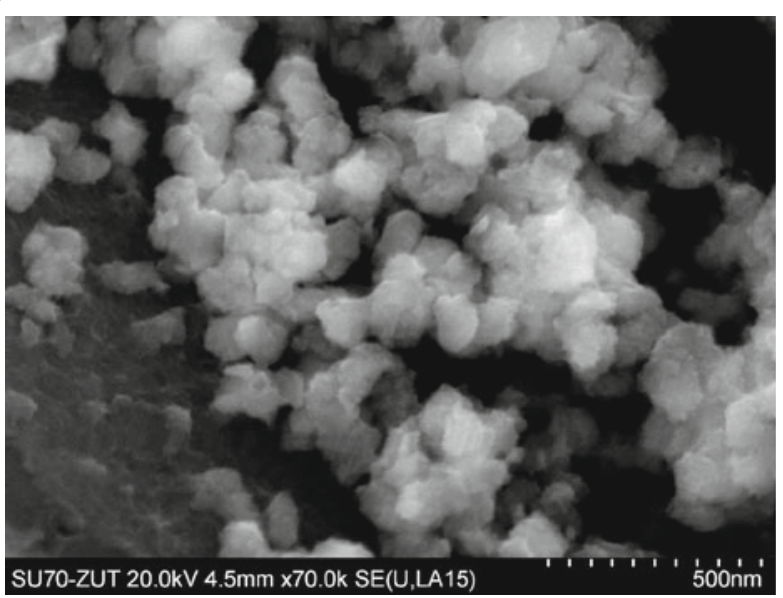

Fig. 3 XRD diffractogram (a) and scanning image (b) of the sample of composition $\mathrm{Mo} / \mathrm{Ti}=1.6$ mole mole ${ }^{-1} ; \mathrm{C} /\left(\mathrm{MoO}_{3}+\mathrm{TiO}_{2}\right)=$ 3 mole mole ${ }^{-1}$ after heating in argon at $1,523 \mathrm{~K}$ for $4 \mathrm{~h}$ 


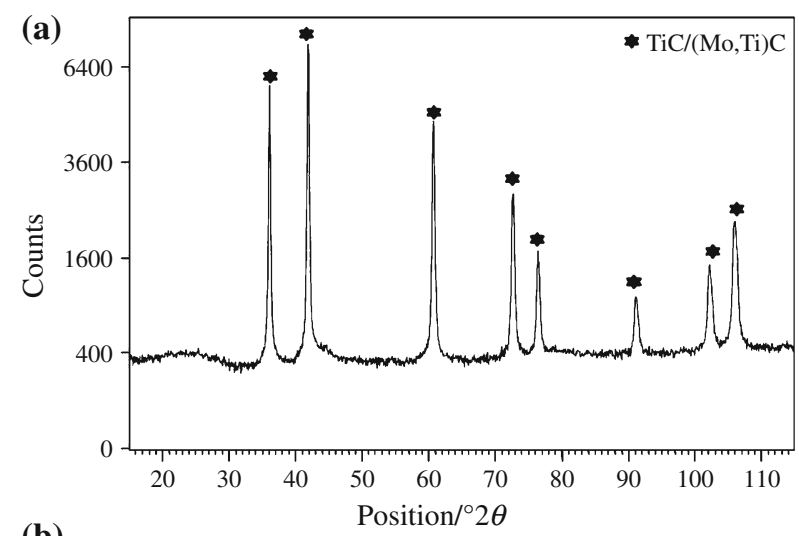

(b)

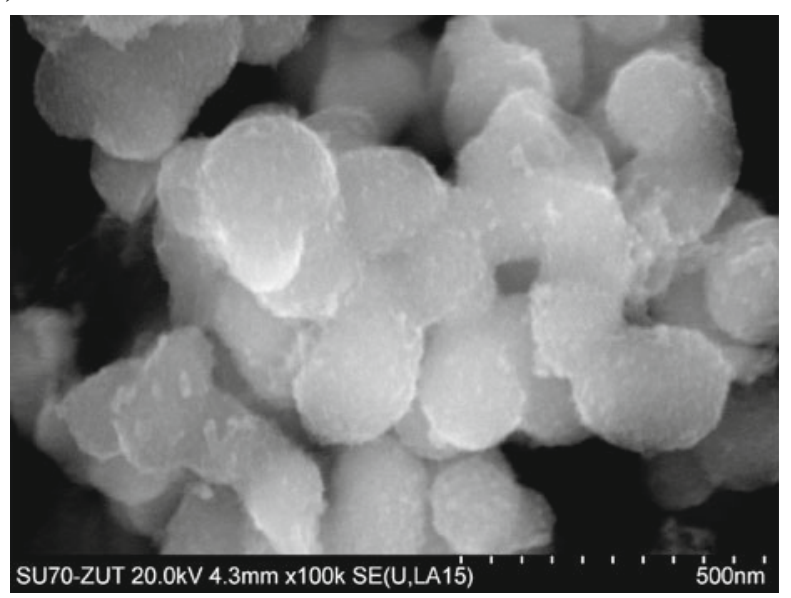

Fig. 4 XRD diffractogram (a) and scanning image (b) of the sample of composition $\mathrm{Mo} / \mathrm{Ti}=0.1$ mole mole $; \quad \mathrm{C} /\left(\mathrm{MoO}_{3}+\mathrm{TiO}_{2}\right)=$ 10 mole mole ${ }^{-1}$ after heating in argon at $1,523 \mathrm{~K}$ for $4 \mathrm{~h}$

The influence of carbon content and molybdenum fraction on phase composition of the final product was also investigated. In the first case the mixtures of invariable composition $\mathrm{Mo} / \mathrm{Ti}=1.6 \mathrm{~mole} \mathrm{~mole}^{-1}$ were used (the samples were heated for $4 \mathrm{~h}$ at 1,523 K) and the carbon content was being changed in the range of 2.5-18.17 mole mole ${ }^{-1}$. In the second case the mixtures of constant carbon content, equal respectively $\mathrm{C} /\left(\mathrm{MoO}_{3}+\right.$ $\mathrm{TiO}_{2}$ ) $=4$ and 10 mole mole ${ }^{-1}$, and the ratios $\mathrm{Mo} / \mathrm{Ti}$ were being changed in the range of $0.1-4.02$ mole mole ${ }^{-1}$. The samples were heated for $4 \mathrm{~h}$ at $1,523 \mathrm{~K}$. The results presented below were obtained for the chosen three samples of the compositions:

a) $\mathrm{Mo} / \mathrm{Ti}=0.1$ mole $\mathrm{mole}^{-1}$;

$\mathrm{C} /\left(\mathrm{MoO}_{3}+\mathrm{TiO}_{2}\right)=10$ mole mole ${ }^{-1}$

b) $\mathrm{Mo} / \mathrm{Ti}=0.4$ mole $\mathrm{mole}^{-1}$;

$\mathrm{C} /\left(\mathrm{MoO}_{3}+\mathrm{TiO}_{2}\right)=4$ mole mole $^{-1}$;

c) $\mathrm{Mo} / \mathrm{Ti}=4.02$ mole mole $^{-1}$;

$\mathrm{C} /\left(\mathrm{MoO}_{3}+\mathrm{TiO}_{2}\right)=4$ mole mole ${ }^{-1}$

In Fig. 4 XRD diffractograms and scanning images of the sample of composition $\mathrm{Mo} / \mathrm{Ti}=0.1 \mathrm{~mole} \mathrm{~mole}^{-1}$;

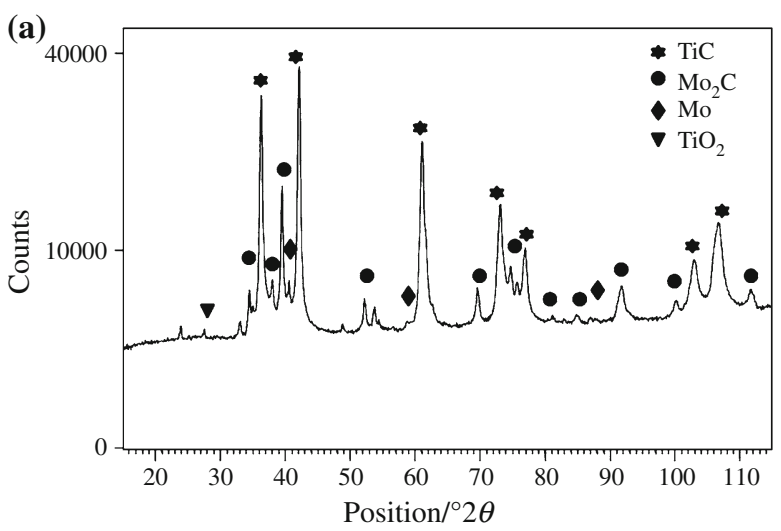

(b)

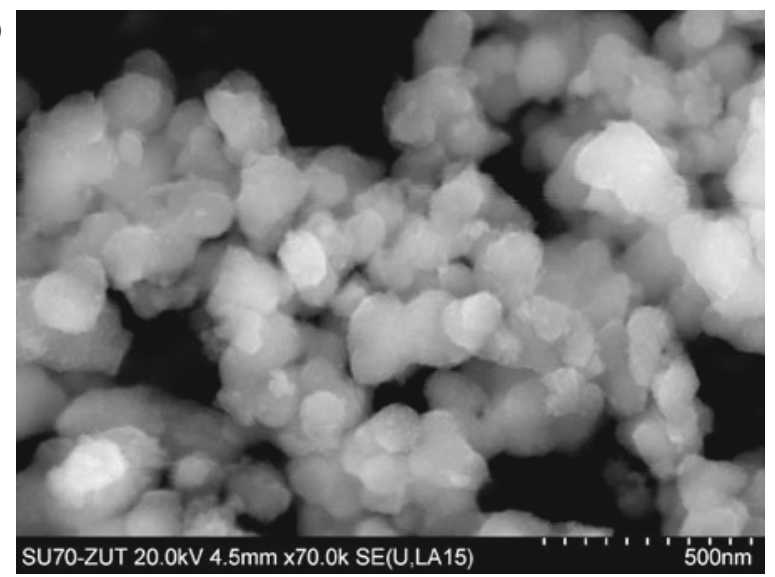

(c)

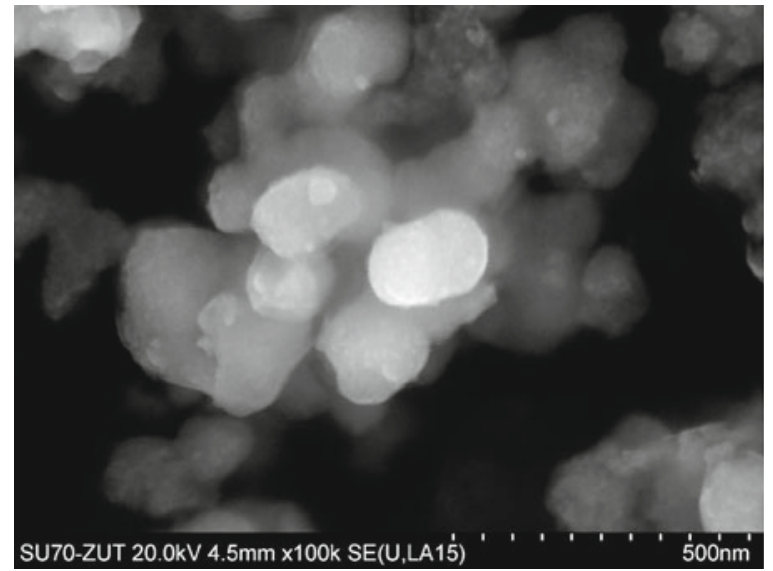

Fig. 5 XRD diffractogram (a) and scanning images (b, c) of the sample of composition $\mathrm{Mo} / \mathrm{Ti}=0.4 \mathrm{~mole} \mathrm{~mole}^{-1} ; \mathrm{C} /\left(\mathrm{MoO}_{3}+\right.$ $\mathrm{TiO}_{2}$ ) $=4$ mole mole ${ }^{-1}$ after heating in argon at $1,523 \mathrm{~K}$ for $4 \mathrm{~h}$

$\mathrm{C} /\left(\mathrm{MoO}_{3}+\mathrm{TiO}_{2}\right)=10$ mole mole ${ }^{-1}$ after heating in argon at $1,523 \mathrm{~K}$ for $4 \mathrm{~h}$ are presented.

The analysis of the phase composition performed by XRD method indicated the presence of TiC (ICDD Card 00-001-1222) and of two components remaining in small amounts i.e. the phase corresponding to (Mo, Ti)C composition and the amorphous carbon.

In Fig. 5 XRD diffractogram (a) and scanning images ( $b, c)$ of the sample of composition $\mathrm{Mo} / \mathrm{Ti}=0.4 \mathrm{~mole} \mathrm{~mole}^{-1}$; 


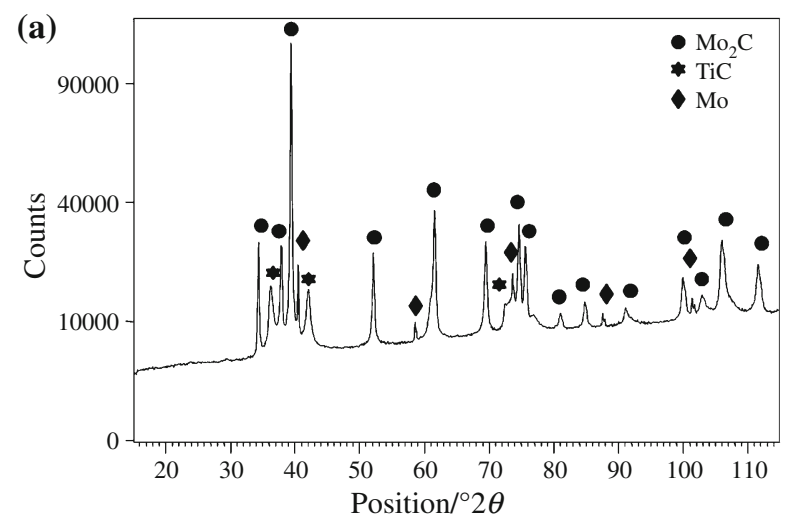

(b)

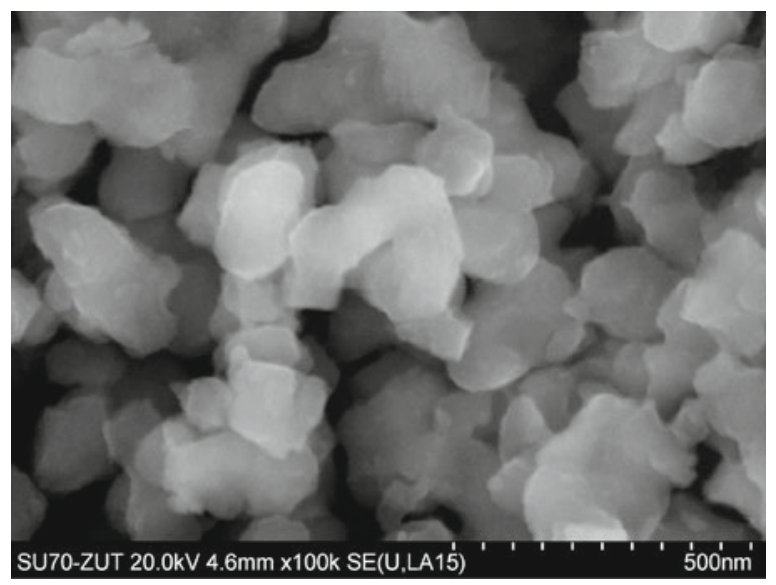

Fig. 6 XRD diffractogram and SEM image of the sample of composition $\mathrm{Mo} / \mathrm{Ti}=4.02$ mole mole ${ }^{-1} ; \quad \mathrm{C} /\left(\mathrm{MoO}_{3}+\mathrm{TiO}_{2}\right)=$ 4 mole mole ${ }^{-1}$ after heating in argon at $1,523 \mathrm{~K}$ for $4 \mathrm{~h}$

$\mathrm{C} /\left(\mathrm{MoO}_{3}+\mathrm{TiO}_{2}\right)=4$ mole mole ${ }^{-1}$ after heating in argon at $1,523 \mathrm{~K}$ for $4 \mathrm{~h}$ are showed.

In this case the dominating phase was TiC (ICDD Card 00-001-1222), and next $\mathrm{Mo}_{2} \mathrm{C}$ (ICDD Card 00-035-0787). Mo (ICDD Card 00-042-1120), $\mathrm{TiO}_{2}$ (ICDD Card 01-0870710) and amorphous carbon occurred as admixtures. In Fig. 5b, c the scanning images of examined material are presented. The EDS analysis of chemical composition demonstrated, that $\mathrm{Mo} / \mathrm{Ti}$ ratio was changing in the range of 0.261-0.29 mole mole ${ }^{-1}$.

Figure 6 presents the XRD diffractogram and scanning image of the sample of composition $\mathrm{Mo} / \mathrm{Ti}=$ 4.02 mole mole ${ }^{-1}, \quad \mathrm{C} /\left(\mathrm{MoO}_{3}+\mathrm{TiO}_{2}\right)=4$ mole mole ${ }^{-1}$ after heating in argon at $1,523 \mathrm{~K}$ for $4 \mathrm{~h}$.

In this sample the dominating phase was $\mathrm{Mo}_{2} \mathrm{C}$ (ICDD Card 00-035-0787). In addition TiC (ICDD Card 00-0011222) and trace amounts of free Mo (ICDD Card 00-0421120) were identified.

The studies on influence of carbon content and molybdenum fraction in initial mixture, allow assuming that, at the molybdenum contents in the range of $0.1 \leq \mathrm{Mo} /$ $\mathrm{Ti}<1.6$, the composite of well-mixed components, in the form of microparticles of titanium carbide containing dispersed nanoparticles of $\mathrm{Mo}_{2} \mathrm{C}$ was obtained. In turn at the ratios of $\mathrm{Mo} / \mathrm{Ti} \geq 1.6$ mole mole ${ }^{-1}$ the composite in the form of $\mathrm{Mo}_{2} \mathrm{C}$ microparticles containing dispersed nanoparticles of titanium carbide was obtained.

\section{Conclusions}

The results of investigations on the simultaneous synthesis of molybdenum carbides and of titanium carbides by sol-gel method have been presented. It was demonstrated, that at low temperature range $\left(\mathrm{NH}_{4}\right)_{6} \mathrm{Mo}_{7} \mathrm{O}_{24} \cdot 4 \mathrm{H}_{2} \mathrm{O}$ decomposes into $\mathrm{MoO}_{3}(t<673 \mathrm{~K})$. During the process the following gases were evolved: $\mathrm{NH}_{3}, \mathrm{H}_{2} \mathrm{O}$ and $\mathrm{NO}$ formed as a result of oxidation of $\mathrm{NH}_{3}$ by the oxygen contained in argon in trace amounts. In temperature range $689-943 \mathrm{~K} \mathrm{MoO}_{3}$ was reduced into $\mathrm{MoO}_{2}$ (or also into Mo). The $\mathrm{CO}_{2}$ was mainly formed during that process. The synthesis of $\mathrm{Mo}_{2} \mathrm{C}$ proceeded in temperature range of $973-1,198 \mathrm{~K}$. During the synthesis of $\mathrm{Mo}_{2} \mathrm{C}$ mainly $\mathrm{CO}$ was formed. In case of the mixtures containing $\mathrm{TiO}_{2}$, synthesis of $\mathrm{Mo}_{2} \mathrm{C}$ and reduction of $\mathrm{TiO}_{2}$ into $\mathrm{Ti}_{x} \mathrm{O}_{y}$, proceeded in similar temperature range. The synthesis of titanium carbides occurred in temperature range $t \geq 1,285 \mathrm{~K}$. Mainly $\mathrm{CO}_{2}$ was evolved in this process.

The investigations on influence of parameters on phase composition of the samples after the synthesis demonstrated that the carbon fraction in the initial mixture, expressed as the ratio $\mathrm{C} /\left(\mathrm{MoO}_{3}+\mathrm{TiO}_{2}\right)$, ensuring total conversion of the substrates, should equal at least 3.5 mole mole $^{-1}$ for $\mathrm{Mo} /$ $\mathrm{Ti}=1.6$ mole mole ${ }^{-1}$. The fraction of molybdenum, expressed as the ratio $\mathrm{Mo} / \mathrm{Ti}$ contained in the range of 0.1-1.6 mole mole ${ }^{-1}$ enables obtaining of the composite in the form of submicron particles of titanium carbide containing dispersed nanoparticles of $\mathrm{Mo}_{2} \mathrm{C}$. At the ratio $\mathrm{Mo} /$ $\mathrm{Ti} \geq 1.6$ mole mole ${ }^{-1}$ the composite in the form of submicron particles of $\mathrm{Mo}_{2} \mathrm{C}$ containing dispersed nanoparticles of titanium carbide was obtained.

Acknowledgments The research was funded by the National Centre for Research and Development in the frame of the realisation of the development project No. 15-0067-10/2010-2013 and the Dean's Grant 'Young Staff' No 517-06-010-3368/17.

Open Access This article is distributed under the terms of the Creative Commons Attribution License which permits any use, distribution, and reproduction in any medium, provided the original author(s) and the source are credited.

\section{References}

1. Takagi K, Osada K, Koike W, Fujima T. Effect of $\mathrm{Mo}_{2} \mathrm{C}$ content on the properties of $\mathrm{TiC}^{\mathrm{T} i B_{2}}$ base cermets. J Phys Conf Ser. 176. 2009. doi:10.1088/1742-6596/176/1/012044. 
2. Biedunkiewicz A, Figiel P, Gabriel-Polrolniczak U, Krawczyk M. Analiza procesów syntezy ceramiki w układach zawierających molibden, krzem i węgiel. Mater Eng. 2012;6(190):597-600 (in Polish).

3. Biedunkiewicz A. Aspects of generation of ceramic nano-materials of type $\mathrm{TiC} / \mathrm{C}, \mathrm{TiC}, \mathrm{TiC}-\mathrm{SiC}-\mathrm{C}$ and $\mathrm{Ti}(\mathrm{C}, \mathrm{N})-\mathrm{Si}(\mathrm{C}, \mathrm{N})-\mathrm{Si}_{3} \mathrm{~N}_{4}$ by the sol-gel method. Szczecin, Poland: West Pomeranian University of Technology; 2009 (in Polish).

4. Preiss H, Berger LM, Schultze D. Studies on the carbothermal preparation of titanium carbide from different gel precursor. J Eur Ceram Soc. 1999;19(2):195-206.

5. Li Y, Yao Y, Shao W, Liu F, Kang Y, Yin G, Huang Z, Liao X. Preparation of titanium carbonitride nanoparticles from a novel refluxing-derived precursor. Mater Lett. 2009;63(22):1904-6.
6. Rambo CR, Cao J, Rusina O, Sieber H. Manufacturing of biomorphic $(\mathrm{Si}, \mathrm{Ti}, \mathrm{Zr}$ )-carbide ceramics by sol-gel processing. Carbon. 2005;43(6):1174-83.

7. Sabara M, Biedunkiewicz A. Analiza procesu syntezy $\mathrm{Mo}_{2} \mathrm{C}$ w układzie $\left(\mathrm{NH}_{4}\right)_{6} \mathrm{Mo}_{7} \mathrm{O}_{24} \cdot 4 \mathrm{H}_{2} \mathrm{O}$-węgiel aktywny. Mater Eng. 2011; 4(182):699-702 (in Polish).

8. Wang X, Zhang M, Qu S. Development and characterization of (Ti, Mo) C carbides reinforced Fe-based surface composite coating produced by laser cladding. Opt Lasers Eng. 2010;48(9):893-8.

9. Eremenko VN, Velikonova TY. Phase equilibria in the Mo-TiC$\mathrm{Ti}$ of the ternary system Mo-Ti-C. Character of solidification of alloys and projection of the solidus surface. Powder Metall Met Ceram. 1969;8(11):931-6. 